\title{
Social Work, Precarity and Sacrifice as Radical Action for Hope
}

\author{
Jonathan Parker \\ Department of Social Sciences \& Social Work, Bournemouth University, BH1 3LT, UK
}

Copyright $(\mathrm{O} 2018$ by authors, all rights reserved. Authors agree that this article remains permanently open access under the terms of the Creative Commons Attribution License 4.0 International License

\begin{abstract}
This paper sets out the history and development of social work, primarily in the UK, in the context of uncertainty and ambiguity. The paper suggests that in an age of increased precariousness, social work itself represents a precarious activity that can be misconstrued and used for political ends as well as for positive change. As a means of countering potentially deleterious consequences arising from this, the concept of sacrifice, taken from Durkheim's research concerning the piaculum, is used to consider social work's societal role as scapegoat on the one hand and champion of the oppressed on the other. The paper concludes that social work's potential for developing and encouraging resilience and hope is indicated in the 'sacrifices' social workers make when walking alongside marginalised and disadvantaged people.
\end{abstract}

Keywords Social Work, Precarity, Sacrifice, Radical Action, Hope

\section{Introduction}

Social work is a slippery and contested phenomenon having many forms and diverse interpretations held by an equally wide range of social actors including those who use social work services, employer organisations, states, professional bodies, and social workers themselves. We all may have some notion of what the term 'social work' means but we consistently fail to capture its many forms and may misinterpret its meaning for others. It is historically and contemporaneously a precarious construct that can be manipulated for many different ends, something that its chequered history also demonstrates, especially within Europe and through its colonial reproductions (Midgely, 1981; Lorenz, 1993; Hugman 2010). This paper considers Western social work's history in the context of contemporary socio-political landscapes of precarity in
Europe. It posits the need, if social work is to achieve its human rights and social justice potential, to rekindle a politically radical form of social work that challenges established and official versions and sits uncomfortably with modern day social, political and educational perspectives. A possible way forward is promoted using a Durkheimian perspective which focuses on the piacular, an expiatory, redemptive and transformatory approach that accords well with social work's radical values, although it can also be used negatively to scapegoat and blame. This approach is exemplified by two case scenarios extended elsewhere (Parker and Ashencaen Crabtree, 2018).

\section{Precarity, the Precariat and Social Work}

Guy Standing (2011) has done much for our understanding of precarity and the precariat. The concept derived, in part, from the neoliberal emphasis on labour market flexibility that arose in the Global North from the 1970 s onwards in response to fiscal challenges and the beginnings of post-industrial production changes. It offered a way of explaining and challenging these developments. Employment became more precarious and uncertain moving away from long-term and fairly stable forms of employment within a trade or profession to instability, uncertainty and, often, short-duration. Standing (2011) went further and defined the precariat as not yet an independent class but becoming a distinct socio-economic group with none of the prior social contract relations and labour securities enjoyed by the proletariat in the past, and having minimal trust relationships with capital or state. Whilst this conception has gained a degree of traction in academic circles, Di Bernado (2016) has pointed out that precarious living has always been expected for many within the Global South and for working class people across the world. Class structures operating throughout the world are fluid and mutable, sharing some commonalities 
with one another but also presenting differences and dichotomies.

If we consider contemporary Europe and the Global North, however, we can use the concept of precarity to point to broad contextual changes within socio-economic and political conditions. For instance, in Italy precariato represents more than just casualised labour, rather precariousness has become a normalised state of living, an insecure, uncertain type of 'living on the margins'. German thinking includes the jobless as well as temporary workers - those with no hope of social integration in the present system - in the precariat. Japan uses the term 'freeter' when describing casual labourers combining the words 'free' and arbeiter. These definitions suggest, as Standing (2011, p. 11) puts it, the lack of a secure work-based identity'. He also adds that it involves 'status discord' drawing attention to the numbers of people with a high level of formal education but only able to gain lower status jobs.

In this paper we will not employ the concept to refer to an emergent class or solely concerned with labour market flexibility but to a political and social situation in which people are forged through neoliberal economics. People who might be described as living precariously have distinctive structures of social income that impart vulnerability. For instance, insecurity in work leads to the lack of a work-based identity and feelings that labour is purely instrumental and opportunistic. It removes feelings of mutuality and community leading to fragmentation and alienation. It also creates a liminal positioning betwixt and between social norms that are representative of power and voice and the marginalised who are stripped of status and do not have access to the parts of society demanding a work-based identity.

When we consider the fluid and precarious nature of contemporary life in the world of work, employment and financial (in)security, migration, changing family and community structures alongside the sense that labour is instrumental, opportunistic and insecure it is clear that many individuals and groups may consider themselves to be part of the amorphous grouping of the precariat. Precarious life, itself, is also associated with increased mental health problems, substance use problems, homelessness, and perceived vulnerability associated with ageing (Nettleton and Burrows, 2011; Evans, 2007; Craciun and Flick, 2014; Canivet et al., 2016; Siernik et al., 2017). The aspects of precarious living mentioned above have wide connections with the world of social work that seeks to promote human rights and social justice as central to its role (IFSW/IASSW, 2014).

The concept of precarity, representing uncertainty and insecurity, is used much more widely that Standing's (2011) preliminary focus on labour flexibility although it is recognised that the global neoliberal political economy embeds labour uncertainties and insecurities as it does in relation to citizenship and other aspects of socio-political life (Schierup and Jørgensen, 2016).

Standing (2011) uses the concept of the denizen to describe many of those people who are located within global insecurities and uncertainties. This is an historical term that refers to someone who is not a full citizen but enjoys a more limited range of rights- whether civil, cultural, social, economic or political. Those in temporary employment, part-time employment, independent and dependent contractors, and interns may become part of the precariat because of their more limited status within contemporary society. This is exemplified within the current Universal Credit system in the UK. The denizen concept mirrors the liminal, neither-one-thing-nor-the-oth er, status carried by the precariat. Social work's role is to move through this social dance towards hope and resilience.

Welfare reform, a euphemism for cutting expenditure and reducing the social protection floor for those living in need have consolidated the diverse mix of benefit paymen ts into an on-line, digitised system (Puttick, 2012; Royston, 2012; Gov.UK, 2017). Whilst there seems to be some sense in simplifying a complexity of benefits the changes are fraught with problems. Not only does this exclude those with limited or no access to the Internet, it has created delays, increased debts by payment in arrears, and reduced income for many (Seddon and O'Donovan, 2013; Hartfree, 2014; Grover, 2015; Hickman et al., 2017). Dean (2012) argues that Universal Credit simply continues a policy initiated by the Speenhamland system in 1795 but that the current moral tone and effects of these welfare changes erode the rights of precarious workers by supporting a highly flexible, precarious labour market. The concerns that have been documented range from people unable to meet rent payments in full, to being forced to use foodbanks and creating distress and disruption in family relationships, and causing tensions between childcare and in-work conditionality (Davey and Hirsch, 2011; Citizen's Advice, 2017; Hickman et al., 2017). Overall, welfare reform in the form of Universal Credit introduced at a time of economic crisis and austerity has expanded conditionality and is premised on increasing punitive sanctions to effect behavioural change, flexibility and precarious living and to enhance power and control over those in such positions (Dwyer and Wright, 2014; Rafferty and Wiggins, 2017).

Precarity may also be conceptualised as a process, which has greater potential for action rather than the stultification that may be associated with it as a collective noun. Standing (2011) states that 'to be precariatised is to be subject to pressures and experiences that lead to a precariat existence, of living in the present, without a secure identity or sense of development achieved through work and lifestyle.' (p.19) Drawing on Morgan's (1999) approach to everyday practices, we can think of people 'doing precarity', although we must remember that this is not an active choice of action but an enforced process that 
illuminates systems of power relations as exemplified by the welfare reforms outlined above. Doing precarity represents a politically imposed act but it is one enshrined within everyday practices and engenders power imbalances, lack of security, uncertainty and ambiguity. The personal distress of people caught at the sharp end of Universal Credit, for instance, and the lack of self- determination and autonomy this engenders is captured well by the blogger, Kate Belgrave, who documents, viscerally, the experiences of those affected by public sector cuts (Belgrave, 2017). This is further exemplified within the sensory-overloaded pace of modern life which promotes further an insecure, precarious mind which is not anchored deeply in concentration and knowledge but flits quickly from subject to subject and leads to superficial views and precarity of mind. The focus on multitasking and information overload leads to stress and lower productivity and reinforces the insecurities experienced in modern life.

This approach to precarity removes the contested and problematic focus on emergent class and draws back to core sociological concepts such as anomie, anxiety and alienation, which in turn may be dialectically realised in transformatory anger. An increasingly surveillance society, in which individuals are exploited and have little influence or voice (Bude, 2018), has led to what Standing (2011) calls a 'politics of inferno'. In turn, this supports the growth of the neo-fascist small state, authoritarian regimes which control through insecurity and fear. This affects migrants, people with disabilities, women and disturbs masculinities, youth and older people. We have seen the growing tendencies to deflect attention from austerity to vulnerable groups in society in Poland, Hungary, post-referendum Britain and in the 2017 German election where the AfD (Alternativ für Deutschland) gained in popularity. Anger is needed to expunge the insecurity and fear and to gain a voice on behalf of the precaritised. A social work that adheres to its human rights credentials as explicated within the international definition can be part of that process of developing resistant anger to oppressive structural impositions (IFSW/IASSW, 2014).

Austerity in England, in particular, has led to a further retrenchment in public services in which a residual social services offering predominantly protection services is available whilst welfare benefits and preventive or transformatory measures required to support life changes have been reduced (Butler, 2017). This has led to growing need, insecurities and uncertainties in families and children in which social workers have, unwittingly, been complicit. There have been continued increases in the number of children who are 'looked after' - those for whom social workers have a statutory responsibility. Between 2010 and 2016 children assessed as being in need rose by $5 \%$, those in care by $10 \%$ (numbering nearly 73,000 in March 2017), and those on Child Protection Plans by 29\% (Department for Education, 2017).

The unevenly distributed access to information and legal justice support also demonstrates precarity (Burridge and Gill, 2017), especially in respect of the most politically, physically and psychologically insecure groups such as refugees and asylum seekers (Şenses, 2016; Babon et al., 2017). There is also a growing focus on sexuality, developing Judith Butler's work that sees sexuality as precarity (Parker, E., 2017). Also, biopolitics expands understandings of precarity to the changing ways the self is perceived and enacted in the world McCormack and Salmenniemi, 2016).

These foci are all of interest to social workers who traverse the pathways and gaps between self-in-the-world and broader organisational and socio-political structures. Ways of mitigating displacement and distress reflect social work's concern. Practitioners seek to co-produce and enact intrapsychic, interpersonal and socio-political methodologies to offset the ravages of neoliberal precarity. Social work's relationship with precarity is manifold and complex, mediated by the role of precariousness in increasing social exclusion and inequalities (Tschöll, 2014); what is clear is that a focus on social justice and human rights is central to offsetting the consequences of precarity.

In the present paper we focus on the wider characteristics of precarity outlined above. Three forms of precarity in social work will be considered. Firstly, we will examine the precariousness of social work as a practice in terms of public perception resulting from its association with marginalised people (dos Santos and Manfroi, 2015; Alves Faerman and Val de Millo, 2016; Cho, 2017; Feldman et al., 2017). We will then consider precarious social work in terms of working for the state to regulate the precariat and precarity within social work organisations/e mployment in times of austerity. Finally, precarious social work will be explored through isomorphic convergence in education and practices which subjects social work to further political influence and control.

The discourses and narratives of social work constructed through these diverse forms create meaning that reinforces stigma, concern and gives power to the policies and technologies of control. The narrative accounts of the person also share a precariousness and fluidity that is acted upon by socio-political change and dependent upon hegemonic dispensation or rejection.

\section{What is Social Work and where has it come from?}

Pinpointing the beginnings of social work is a political act in itself, creating discourses by the privileging of certain aspects of history over others (Payne, 2005; Parker and Ashencaen Crabtree, 2018). This political context shows the uncertainties and insecurities associated with social work itself in society, its tenuous and ambivalent position and its potential to oppress as well as to fight injustice. 
If we consider the nineteenth century as the crucible of growth of modern British social work it is clear that there are multiple perspectives and activities underpinning it. For instance, the moralising dimension of the Poor Law (Amendment) Act of 1834 emphasising the distinctions between deserving and undeserving, the needy and the feckless was continued in, by and through the work of the Charity Organisation Society in the latter half of the nineteenth century and has undergirded means-testing, eligibility criteria and moral debate since. These discourses have underpinned welfare's complicity in the continual creation of the precariat. Another strand focuses on the socio-political developments that demanded reform, state intervention and radical political change through the work of key social reformers and liberal and labour politicians (Renwick, 2017). This was sometimes undertaken to offset the potential for revolution and to ensure those in need remained loyal to the existing political system but was at other times driven by compassion for change. Yet another factor in social work's varied development relates to religious help and charity, something which permeated society through the work of the monasteries until dissolution and continued through Parish organisation of the Poor Law and the creation of charitable bodies with specific responsibilities for working with prostitutes such as Ellen Ranyard's Bible and Domestic Female Mission founded in 1857 (Prochaska, 2006), the Salvation Army working with alcohol problems and temperance from 1865 (Murdock, 1994) and the probation of offenders (Vanstone and Priestley, 2016).

Of course, social work has a much longer history than the nineteenth century, should we wish to look for it and depending on our definition of it. However, the more formalised, bureaucratic technologies of social welfare associated with twentieth and twenty-first century iterations can be readily traced to a range of these developmental trends. For instance, the residual element of relief provided by the reformed Poor Law in Britain and its focus on data collection, and administrative bureaucracy, the development of social casework in the Charity Organisation Society, the development of social insurance in Bismarckian German, Catholic relief in Spain and so on. Social work has been intimately bound with precariousness at the hinterlands of social and political life (Zaviršek and Lawrence, 2012; Parker and Ashencaen Crabtree, 2018). There has been an international aspect to the development of social work since the nineteenth century particularly reflected in the growth of social work in the United States, again demonstrating both individual/moral approaches and corporate political ones (Agnew, 2004; Addams, 2012).

The politics of social work allow us to reflect on the global definition and standards that have developed and to challenge the imposition of the single homogenised approach. This was successfully addressed in revising the definition in 2014 when individual states were acknowledged as having singular foci that should be included, thus allowing for authentic cultural representations rather than Westernised or even narrower definitions being imposed on them. This in itself suggests precarity. It shows the fluid, mutable definition and understanding of social work. It demonstrates the dangers of power relations if not acknowledged and considered critically.

Social work education also developed within this complex mix of political, governmental and charitable approaches. This had an increasingly international flavor since the late nineteenth century, beginning in the UK, USA and Germany and spreading throughout the world during the twentieth century (see Edinburgh University, N.D. for a chronological timeline). Social work education developments globally have been driven by good intention but sometimes with a worrying neocolonial perspective that assumed the rightness of accepted approaches from high-income countries of the Global North, which demands critical resistance (Abram, 2004; Sinclair, 2004; Lewis, 2011).

\section{Precarious Social Work}

Since the 2008 financial crisis European societies have embraced and promoted austerity as a means of tackling national debt, the rolling back of state involvement in public services and social action (Mendoza, 2015). It is a homogenising action that bolsters governments, banks and multinational business and has driven a wedge between power and those who rely most on those services (Varafoukis, 2017). In turn those in power, and with much to lose, have been complicit in passing the blame for poverty, unemployment, lack of opportunity, poor housing, high rents and residualised social services on to sections of society made most vulnerable by these actions such as migrant groups. This deflects blame from government decisions to adopt austerity measures and maintains their power. More sinister is the support this lends to the rise of populist, right-wing politics amongst those who rely on those services. The North American novelist of the early $20^{\text {th }}$ century, Jack London, puts the dilemma well when living amongst the poor and rough sleepers in London's East End:

The agreement is that kipping, or dossing, or sleeping, is the hardest problem they have to face, harder even than that of food. The inclement weather and the harsh laws are mainly responsible for this, while the men themselves ascribe their homelessness to foreign immigration, especially of Polish and Russian Jews, who take their places at lower wages and establish the sweating system (London, 1902, p. 44)

The rise of ADF in Germany, Lega Nord in Italy, Golden Dawn in Greece and Britain First in the UK amongst others offer clear examples of the dangerous politics resulting from a combination of austerity measures and post-truth 
mythologies. This has led to concerns regarding the access to health and social are services by people of precarious immigration status (Brabant and Raynault, 2012; Vanthuyne et al., 2013; Gea-Sánchez et al., 2017)

\section{Social Work as State Agents}

Social workers operate in these socially, politically and economically impoverished circumstances. Where social work forms part of a state system resources are severely constrained and tighter and more rigorous eligibility are applied. When working for third sector or civil society organisations, grants supporting services have been restricted and funding reduced making the provision of social work support less available. As argued elsewhere social work's associations with those who are disenfranchised or made deviant by society leads to a public distrust and dislike (Parker, 2007; Parker and Ashencaen Crabtree, 2018a). Indeed, if we look at the reaction of politicians, and the general public, fuelled by media hatred after the report into the death of Baby Peter was released (2009; Parker and Ashencaen Crabtree, 2018b) we see social work itself made deviant and social workers blamed for society's ills (Jones, 2014; Shoesmith, 2016). Reactions to the news of an increase in child mortality as a whole in 2015 were muted by comparison, perhaps because this takes a wider structural view rather than one in which blame can be apportioned (Office of National Statistics, 2015).Working alongside parents who have abused their children, children who have been damaged, with rough sleepers, people who misuse alcohol and drugs and those with mental health problems taints social workers themselves with the perceived wrongs and disadvantages of those people. Politicians and the general public then act against social work as a carrier of wrong and shun the profession, seeing it as something to be avoided and dismissed, despite their assumption of its necessity, rather like the Dalit or untouchable caste of pre-independence India. However, complicity with austerity by increasing the number of Child Protection Plans, demonising families and stigmatising children by increased care proceedings runs against the grain of a social work that privileges social justice and human rights (Department for Education, 2017). Social workers are pushed into an impossible position in which they cannot act without attracting opprobrium.

Social workers are in a vulnerable or precarious position also if they try to follow the lines taken by their organisations, in beginning to believe and apply the myths constructed to feed the notion of austerity's necessity; they become complicit with the oppression of others and, therefore, act counter to the agreed international value perspectives of social work. Being part of the state's apparatus of social regulation and control rubs against the grain of a commitment to human rights and social justice and makes the survival of social work as a meaningful entity less secure and more uncertain. In Britain and
England especially, social work has been severely constrained by austerity measures as most social workers are employed within local government (Department for Education, 2018). As the need to drive down costs leads to a reduction in numbers of social workers employed so too is the role redefined through the development of standards of proficiency (HCPC, 2012) and Knowledge and Skill Sets (Department for Education, 2014; Department of Health, 2015). Social workers in this scenario are increasingly seen as the agent of the state, quite rightly publicly accountable but more equivocally socially controlled. They are responsible for social regulation of behaviour, attitudes and of those placed in a position of vulnerability as a result of structural matters such as welfare reform, revised eligibility criteria and reduced access to public services driven by tacit assumption and ideology.

\section{Precarious Social Work Education}

Finally, the precarity of social work in the UK is confirmed by an increasingly regulated and prescribed education system that removes responsibility from the universities and replaces it with socio-political economic measures aimed not at human distress and need but at societal functioning and instrumentality. UK government involvement in the revision of social work education has been continual since 2003 and is based on a premise that education to date has not been 'fit for purpose', that politicians and employers held the key to effective reform and to deflect attention away from structural and political ills (Jones, 2014). Social work educators need to fight to retain the human, relational element and to ensure there remains innovation within social work qualifying programmes and hope for those who use them (Garrett, 2010; Parker and Ashencaen Crabtree, 2018b). Of course, this situation differs in other countries (see Nikku and Hatta, 2014). It should be seen as a caveat to increased government involvement in curriculum design and educational prescription (Parker et al., 2016).

\section{Radical Social Work and Radical Social Action}

The halcyon days of radical social work have perhaps been somewhat mythologised but the recognition of a political focus continues at a macro policy level which emphasises social justice and human rights in social work practice. State mandated social work may use the technologies of care to exert control and to diminish the appetite for social action. This may not be an entirely conscious process but it is one that prevents full participation in social change by citizens and the disenfranchised. In this sense social work either forms part of the privileged structures that reinforce austerity or it 
seeks to challenge it.

Arguments from the perspective of moral economy are particularly pertinent to social work given their focus on mutuality which are akin to co-creative approaches to socio-political and ecological problems facing people in late modern societies (Thompson, 1971). Promoting a moral economy challenges neoliberal emphasis on the ultimate power of the market in determining futures and its demand for flexibility, insecurity and precariousness in life. It also enjoins with social work's ethos and values. It must be questioned how this might this work in practice. A recent discussion with 'Vic' (pseudonym), a social worker practising with adults with diverse needs resulting from acquired or long-term disabilities, health problems and difficulties with everyday living, provides an example to understand how practice can address some of the complexities arising from precariousness within a state controlled social work environment.

Vic moved into an assessment team after the social services area he worked in was restructured. Prior to this he had been part of a long-term support team in which relationships were paramount to effecting mutually agreed change. In his first week Vic was asked to make an assessment of a man, James, who was paraplegic since a motorcycle accident. The assessment concerned James' 'needs' as he perceived them as legislation required and had to be undertaken in a timely manner. Vic was aware of the time pressures that his new teams were under and of the paperwork necessary to complete the assessment.

Vic met with a very angry James who became even angrier as he asked him about his ability to undertake activities of daily living and said his only need was to have his piano restrung. He explained that he was a former concert pianist and his bitterness at not being able to continue this following his accident meant that he had taken a hammer to his piano damaging it so badly that it would no longer play. Vic was taken aback and tearing up what he had written asked if he could start the assessment again. James agreed and Vic simply asked James to describe what he felt he needed, to tell his story. James talked at length; glad of the opportunity, and Vic did not undertake an assessment as required by his office but agreed to see how he could help James with his identified needs. He gave priority to the relationship.

The resurgence of radical approaches to social work, seen in such organisations as the Social Work Action Network (SWAN), offers a much needed corrective to neoliberal state-sponsored social work which so often acts as a means if mitigating social responsibility for private ills resulting from the structural, and challenges accepted power relations.

Social work throughout Europe treads a difficult path between its obligations to social, governmental and legislative systems and to the people it serves often on the margins of those societies and often as a result of the ways in which those social systems operate (Parker and Ashencaen Crabtree, 2018a). The political and organisational contexts of social work are influenced by a country's history and the political and professional discourses underpinning it (Payne, 2012). Whilst most countries are influenced by a mix of political philosophies, the axiological foci of social work on social justice and human rights veer towards a social democratic approach. Where a country espouses authoritarian or neoliberal principles, as has been the case throughout Europe reinforced through the imposition of austerity measures, autonomy, human rights and social justice suffer. Social work must therefore stand against these trends. To be true to social work as embraced by the IFSW, however, it is incumbent on practitioners to stand alongside those who are marginalised and to consider the moral economic challenge to attack established and taken-for-granted assumptions that collude with, if not cause, people's marginalisation. A good example of radical social work in action that removes itself from the constraints of local government has been seen in work done with migrant groups in Calais (Ivory, 2017).

A way of understanding social work in these precarious, fluid and uncertain contexts is to use a Durkheimian analysis of piacular rites to illuminate social work pathways to change and development (Durkheim, 1912/2001). Whilst this reflects a theorisation of social work practice, it is one which sits well with a politically radical approach, focusing, as it does, on the transformatory rituals engaged in to effect relief from distress and suffering. It provides anthropology of praxis that is potentially bifurcated; it may absolve the state from responsibility by deflecting attention, or it works with the suffering of the oppressed through a transformatory praxis.

\section{Piacularism in Social Work}

Durkheim (1912/2001), in his The Elementary Forms of Religious Life, suggested that ceremonies or rites associated with coping with distressing and frightening catastrophes that often invoke fear and anguish took a particular form. He used the term piacular, which suggests expiation or transformatory sacrifice, to describe these ceremonies. The word is taken from the Latin piaculum which has multiple meanings such as victim, sacrifice, atonement, punishment, crime or sin. A piacular rite represents the expression of community solidarity in times of crisis. The rites of the group can be harnessed on behalf of the many.

Social workers can be construed as modern day piacula in the two ways described above. They may represent a victim tainted by association with a social 'wrong' who can 
through ritual punishment (in the media) and sacrifice (by losing one's job) atone for the 'sins' of society. In such an understanding social workers are much needed instruments of society because they can be sacrificed to maintain the status quo or deflect attention from matters of social concern and structural problems. However, the other way in which expiation can be made through social workers is to stand besides people experiencing the consequences of contemporary societies and use the guilt and fear expressed in and by society to champion new understandings and to promote the wellbeing of those oppressed groups with whom they work. Returning to Vic's story can help exemplify this:

On his return to the office, having taken an hour and a half longer than he ought, his manager asked what he had been doing. When he described his meeting with James and what had been discussed and agreed, he was berated in front of his colleagues for 'not doing his job' and was threatened with a disciplinary hearing should this occur again. Vic stood his ground, worked to get James' piano fixed but was ostracised by his colleagues and manager, associated as he was with deviant behaviour by focusing on the relationship with James and what James believed he needed. He was forced to look for another job albeit within the same social services department but he had created much discussion within the team.

Durkheim (1912/2001) developed his ideas concerning sacrifice from the mourning rites of indigenous Australian peoples in which deep sadness often turned to anger and subsequently to ritualised violence against oneself or certain prescribed other members of the group. In contemporary society, we can see the 'others' as the social workers who are attacked and violated by the establishment. Durkheim understood these as communal displays of suffering in which the self-inflicted pain and wounds express explicitly that one is suffering. They represent a duty imposed by the group, an obligation to lament that is performed out of respect for custom rather than because of any individual affective state.

We can see in many of the communities with which social workers practise an internalised frustration and violent ritual in which the 'feared other', the social worker, is loaded with the guilt and oppression enacted by and through societal structures on the individuals and communities. The social worker, as an establishment employee, is a symbolic reminder of the oppression and distrust that has led to their precarious standing. The social worker embodies structure against the person. Alongside this, society and employers also demand that social workers can and must carry these wrongs thus mitigating social wrongs. In this way the rituals of practice serve to salve the pain of both the recipients and employers of social work. However, this can act against meaningful change, serving rather to provide first aid, a sticking plaster, to those made vulnerable in society and and to keep the painful realities of society away from the 'general public' who are not in this position.

Following the publication of the report into the death of Baby Peter, politicians and media piled the guilt and perceptions of anguish and wrong onto the social workers and director of children's services, publicly castigating them and their failings (Ball, 2009; Jones, 2014; Shoesmith, 2016). This led to calls for revenge and punishment enacted by sackings, disciplinary hearings and public humiliation. Social workers and managers acted as a piaculum carrying the guilt of reductions in public services and their funding, lack of political commitment to social work employees, and as a sacrifice to ensure continued public support for the politicians and, no doubt, to create a psycho-social defence against the 'feared other', the abusers - in this case Steven Barker and Tracey Connelly.

However, the social worker is more than a state operative. Social work offers a way of standing firm against the power of fear, by challenging, communicating and protesting through ritual actions of resistance, resilience and hope which also remove the supposed uncleanness of those people who are marginalised and oppressed, as shown by Vic's actions in the vignette above. As local governments become more entrenched within austerity, social work must be practised outside its structures. State sponsored social work has been manoeuvred into becoming part of the problem and, to correct the social justice and human rights abuses that late modern life inflicts upon the people, social work must align itself with those in uncertain, insecure positions. Whilst such a positioning accord well with social work values, the insecurities of social workers as local government employees indicates these commonalities. A case example may help here.

Sharon, a former nurse, had multiple sclerosis and a range of debilitating health problems. She had recently had a full assessment of her needs but identified numerous factual errors in the report that she wished to have corrected. Bringing the errors to the attention of social services appeared to set in train actions designed to show power and to offset any need for change and certainly no admission that anything in the report was incorrect. A meeting was called in which Sharon was to attend to speak with her social worker and her social worker's manager. She had been in similar situations before in which the process was made uncomfortable and the meeting intended to underline the balance of power between her and services. Fortunately, Sharon was able to take an independent social worker with her to the meeting. Although the independent social worker took very little part her presence ensured that Sharon was treated with respect and listened to and this small act of resistance meant that the required changes to the assessment were made. 
In the mourning rituals Durkheim reported, grief is intensified when it is expressed collectively and this solidarity of action allows a transformation to take place through the rite of mourning which in turn makes the mourned for a feared and 'othered' entity. A radical approach to social work practice would see the facilitation of a collective response to people's need and/or oppression as necessary to effecting change. The mourned for entity represents the regaining of lost voice and security of status that is now longed for but equally feared as demanding action and relative autonomy between people. It requires a transformatory rite to expiate the wrongdoing of the state, a sacrifice which social work can provide alongside the people by exposing the wrongs done to the people and standing beside the people as they work together to change them. Durkheim goes further in his explanation suggesting the rite itself, without supernatural ascription, is seen to act to effect a change, working through the collective forces that it sets in motion. Since misfortune threatens the collectivity or social group as a whole, sharing and intensifying the anguish allows the group to ameliorate the effect through the rite of punishment inflicted by expiation as a manifestation of public anger. Social workers can make a revolutionary sacrifice through practice which explicitly recognises the positions of those with whom they work and the ways in which social structures and organisations have contributed to their suffering. It is important here, however, to be aware of the dangers of developing a mythology around social worker as saviour and to place faith in charisma and personality rather than shared praxis.

Durkheim suggests that religious life gravitates around two opposing but also sustaining forces or poles - the pure and the impure, the sacred and the profane. These binary forces are also seen in society and social life. The place of these forces on the poles can change through the ritual, the unclean may become an instrument of purification.

We can see a similar social process happening within the metaphorical ritual slaughter enacted by media and politicians after high profile tragedies such as Baby Peter and Daniel Pelka (Jones, 2014; Kettle, 2015; Shoesmith, 2016; Coles et al., 2016). Despite need and risk in child and family social work increasing with economic, educational and labour precariousness (Álvarez-Dardet et al., 2016), the social worker is heaped with guilt, sin, impurity when things go wrong and this requires expiation. As we have noted, the social worker is duly sacrificed and that sacrifice is employed to bolster the political elite and the status quo (Worrell, 2015). This kind of scapegoat or sacrificial rite is complicit, however, with a state social work that fails to support those who require its services.

When society encounters circumstances that sadden, anguish, or irritate it, it exerts pressures on its members to bear witness to their sadness, their anguish, or their anger through expressive acts. It imposes in them something like a duty to weep, wail, and inflict wounds on themselves or others, for these collective demonstrations and the moral communion they express restore to the group the energy that events were threatening to take away, and this enables the group to recover itself. (Durkheim, 1912/2001, p. 307)

Robinson (2006) takes this concept further showing that in ritual private identity is replaced by a collective identity manifested within it, which allows release from the situation of distress. It is here that the social worker has positive potential by walking in solidarity alongside those people whom society has pushed into mourning, distress and liminality. By standing with them social workers act as part of a collectivity to enhance human rights and social justice through the voices of the oppressed and make a shift from distress. It is this act that attracts society's opprobrium whilst at the same time removing the stain on society. Such a view may be accused of functionalism and yet the dialectic nature of the change in dialogue guards against such, suggesting that the new replaces the fixed and the assumed.

\section{Conclusions}

Ritual and sacrifice represent dynamic techniques of resisting the damaging precarity of social work and those who use social work services that is experienced under neoliberal policies. It offers hope. If social workers remain part of the system their rituals simply assuage the guilt of those with power. If social workers resist the status quo and stand alongside the precariat, understood in a much wider sense than labour flexibility, they have a chance to transform society and the lives of those with whom they practise.

\section{Acknowledgements}

With thanks and gratitude to Dr Magnus Frampton at Univeristät Vechta, Germany for the invitation to present a keynote from which this paper emanated.

\section{REFERENCES}

[1] Abram, F.Y. (2004) A re-conceptualization of 'reverse mission' for international social work education and practice. Social Work Education. 26(1), 3-19.

[2] Addams, J. (2012) Twenty Years at Hull House. Ne York: Dover Publications.

[3] Agnew, E.N. (2004) From Charity to Social Work: Mary E. Richmond and the creation of an American profession. Chicago: University of Illinois Press. 
[4] Baban, F., Ilcan, S. and Rygiel, K. (2017). Syrian refugees in Turkey: Pathways to precarity, differential exclusion, and negotiated citizenship rights. Journal of Ethnic and Migration Studies. 43(1), 41-57.

[5] Belgrave, K. (2017) Universal credit and tax credit debt collection - wtf is going on here. My god, 6 Oct. Retrieved 13 October 2017

http://www.katebelgrave.com/2017/10/universal-credit-and -tax-credit-debt-collection-wtf-is-going-on-here-my-god/.

[6] Bude, H. (2018). Society of Fear (transl. Jessica Spengler), Cambridge: Polity Press.

[7] Burridge, A. and Gill, N. (2017). Conveyer-belt justice: Precarity, access to justice, and uneven geographies of Legal Aid in UK asylum appeals. Antipode, 49(1), 23-42.

[8] Butler, P. (2017). Austerity record blamed for record numbers of children taken into care. The Guardian, 11 Oct, Retrieved 11 October 2017

https://www.theguardian.com/society/2017/oct/11/austerit y-policy-blamed-record-numbers-children-taken-into-care.

[9] Citizen's Advice (2017). Universal Credit expansion is a 'disaster waiting to happen' say Citizen's Advice. Retrieved 3 Oct 2017

https://www.citizensadvice.org.uk/about-us/how-citizens-a dvice-works/media/press-releases/universal-credit-expansi on-is-a-disaster-waiting-to-happen-says-citizens-advice/.

[10] Coles, E., Cheyne, H., Rankin, J. and Daniel, B. (2016) Getting It Right for Every Child: A National Policy Framework to Promote Children's Well-being in Scotland, United Kingdom, The Milbank Quarterly, 94(2), (334).

[11] Davey, C. and Hirsch, D. (2011) Chidcare in Universal Credit: Will work pay for single parents? Journal of Poverty and Social Justice. 19(3), 289-294.

[12] Dean, H. (2012) The ethical deficit of the United Kingdom's proposed Universal Credit: Pimping the precariat. Political Quarterly. 83(2), 353-359.

[13] Department for Education (2018) Experimental statistics: Children and family social work workforce in England, year ending 30 September 2017. SFR 09/2018, Retrieved 15 February 2018.

https://assets.publishing.service.gov.uk/government/upload s/system/uploads/attachment data/file/681546/SFR09-201 8 Main Text.pdf

[14] Department for Education (2017). Children Looked After in England (including adoption) year ending 31 March 2017. SFR 50/2017 28 September 2017. Retrieved 13 October 2017

https://www.gov.uk/government/uploads/system/uploads/a ttachment data/file/647852/SFR50 2017-Children looked _after_in_England.pdf.

[15] Durkheim, E. (1912/2001). The Elementary Forms of Religious Life. Oxford: Oxford University Press.

[16] Dwyer, P and Wright, S. (2014). Universal Credit, ubiquitous conditionality and its implications for social citizenship. Journal of Poverty and Social Justice. 22(1), 27-35.

[17] Edinburgh University (N.D.) Social Work at Edinburgh University - Timeline. Retrieved 6 July 2018 http://www.socialwork.ed.ac.uk/centenary/timeline.

[18] Gov.UK (2017). Universal Credit. Retrieved 11 October 2017 https://www.gov.uk/universal-credit.

[19] Grover, C. (2015). From wage supplements to a 'living wage'? A commentary on the problems of predistribution in Britain's summer budget of 2015. Critical Social Policy. 36(4), 693-703.

[20] Hartfree, Y. (2014). Universal Credit: the impact of monthly payments on low income households. Journal of Poverty and Social Justice. 22(1), 15-26.

[21] Hickman, P., Kemp, P.A., Reeve, K. and Wilson, I. (2017). The impact of the direct payment of housing benefit: evidence from Great Britain. Housing Studies. 32(8), 1105-1126.

[22] Hugman, R. (2010). Understanding international social work: A critical analysis. Basingstoke: Palgrave Macmillan.

[23] Ivory, M. (2017) Should social workers be political activists? The Guardian, 26 ${ }^{\text {th }}$ May. Retrieved 11 October 2017 https://www.theguardian.com/social-care-network/2017/m ay/26/should-social-workers-be-political-activists.

[24] Lewis, E.A. (2011) Cultural differences and neo-colonialism in social work: negotiating exchanges between Ghana and the United States. Reflections: Narratives of Professional Helping. 17(3), 31-37.

[25] Lorenz, W. (1994). Social Work in a Changing Europe, London: Routledge.

[26] Kettle, M. (2015). The tipping point: Fateful moments in child protection. Child and Family Social Work, First published: 24 August 2015, https://doi.org/10.1111/cfs.12253.

[27] McCormack, D. and Salmenniemi, S. (2016). The biopolitics of precarity and the self. European Journal of Cultural Studies. 19(1), 3-15.

[28] Midgely, J. (1981). Professional Imperialism: Social work in the third world. London: Heinemann.

[29] Murdock, N. (1994). The Origins of the Salvation Army. Oregon: Wipf and Stock.

[30] Nikku, B.R. and Hatta, Z.A. (eds) (2014) Social Work Education and Practice: Scholarship and innovations in the Asia Pacific. Sydney: Primrose Hall Publishing Group.

[31] Office of National Statistics (2015). Childhood Mortality in England and Wales 2015. Retrieved 9 October 2017 https://www.ons.gov.uk/peoplepopulationandcommunity/b irthsdeathsandmarriages/deaths/bulletins/childhoodinfanta ndperinatalmortalityinenglandandwales/2015.

[32] Parker, E. (2017). Precarity and elemental difference: On Butler's rewriting of Irigarayan difference. Political Theory, 45(3), 310-341.

[33] Parker, J. and Ashencaen Crabtree, S. (2018). Social Work with Marginalised and Disadvantaged People. London: Sage.

[34] Parker, J., Ashencaen Crabtree, S. \& Azman, A. (2016) Treading the long path: Social work education in Malaysia, 
in Taylor, I., Bogo, M., Lefevre, M. and Teater, B. (eds) (2016) The Routledge International Handbook of Social Work Education, London and New York: Routledge, pp. 84-95.

[35] Payne, M. (2012). Political and organisational contexts of social work internationally. In K. Lyons, M. Pawar, N. Huegler and Hall, N. (Eds.) The Sage Handbook of International Social Work. London: Sage, 121-135.

[36] Prochaska, F. (2006). Christianity and Social Service in Modern Britain: The disinherited spirit. Oxford: Oxford University Press.

[37] Puttick, K. (2012). ' $21^{\text {st }}$ Century Welfare' and Universal Credit: Reconstructing the wage-work-welfare bargain. Industrial Law Journal. 41(2), 236-249.

[38] Rafferty, A. and Wiggins, J. (2017). The time-related underemployment of lone parents during welfare reform, recession and austerity: a challenge to in-work conditionality. Social Policy and Administration. 51(3), 511-538.

[39] Robinson, K. (2006). Marx, Durkheim and Weber: Foundations of modern social thought. $2^{\text {nd }}$ edition. London: Sage.

[40] Royston, S. (2012). Understanding Universal Credit. Journal of Poverty and Social Justice. 20(1), 69-80.

[41] Schierup, C-U. and Jørgensen, M.B. (2016). An introduction to the special issue. Politics of precarity: Migrant conditions, struggles and experiences, Critical Sociology, 42(7/8), 947-958.
[42] Seddon, J. and O'Donovan, B. (2013). The Achilles' heel of scale service design in social security administration: The case of the United Kingdom's Universal Credit. International Social Security Review. 66(1), 1-23.

[43] Şenses, N. (2016). Rethinking migration in the context of precarity: The case of Turkey. Critical Sociology. 42(7/8), 975-987.

[44] Sinclair, R. (2004) Aboriginal social work education in Canada: Decolonizing pedagogy for the seventh generation. First Peoples Child and Family Review. 1(1) 49-61.

[45] Thompson, E.P. (1971). The Moral Economy of the English Crowd in the Eighteenth Century, Past \& Present 50, 76 136.

[46] Vanstone, M. and Priestley, P. (eds) (2016). Probation and Politics: Academic reflections from former practitioners. Basingstoke: Palgrave.

[47] Wall, M., Campbell, M. O. and Janbek, D. (2017). Syrian refugees and information precarity. New Media and Society. 19(2), 240-254.

[48] Worrell, M.P. (2015). Imperial homunculi: The speculative singularities of American hegemony (Drones, suicide bombers, and rampage killers, or, am excursion into Durkheimian geometry. In H.F. Dahms (ed.) Globalization, Critique and Social Theory: Diagnoses and challenges. Bingley: Emerald, 217-242.

[49] Zaviršek, D. and Lawrence, S. (2012). Social work in Europe. In K. Lyons, M. Pawar, N. Huegler and Hall, N. (Eds.) The Sage Handbook of International Social Work. London: Sage, 436-450. 